\title{
MENINGKATKAN KEMAMPUAN GENERALISASI MATEMATIK DAN KEPERCAYAAN DIRI SISWA SMP DENGAN PENDEKATAN METAPHORICAL THINKING
}

\author{
Leni Andriani Lesmana1, Wahyu Hidayat ${ }^{2}$, Euis Eti Rohaeti ${ }^{3}$ \\ 1,2,3 IKIP Siliwangi, Jl. Terusan Jendral Sudirman. Cimahi

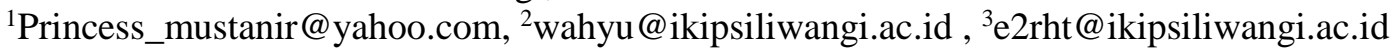

\begin{abstract}
This study aims to determine the increased ability of mathematical generalization and self-confidence of students junior hight school with Methaporical Thinking approach. The research method used is an experimental method involving 2 classes, namely experimental class and control class. The sample of this study was chosen randomly with the number of samples were 30 students of class XII at SMP RAHAYU. And elected class 7-1 as experimental class and class 7-2 as control class. In each data collection each student will be given the same pretest and postes. Intrument used is a test of mathematical generalization ability and scale of confidence. From the calculation and hypothesis test, it can be concluded that the improvement of mathematical generalization ability of the experimental class is significantly better than the control class, then most of the students who get the learning with methaporical thinking had better self confidence than ordinary learning.
\end{abstract}

Keywords : Generalization ability, Self Confidence

\begin{abstract}
Abstrak
Penelitian ini bertujuan untuk mengetahui peningkatan kemampuan generalisasi matematik dan kepercayaan diri siswa SMP dengan pendekatan Methaporical Thinking. Metode penelitian yang digunakan adalah metode eksperimen yang melibatkan 2 kelas, yakni kelas eksperimen dan kelas kontrol. Sampel penelitian ini dipilih secara acak dengan jumlah sampel adalah 30 orang siswa smp kelas XII di SMP RAHAYU. Dan terpilih kelas 7-1 sebagai kelas eksperimen dan kelas 7-2 sebagai kelas kontrol. Dalam pengumpulan data setiap siswa masing-masing akan diberikan pretes dan postes yang sama. Intrumen yang digunakan adalah tes kemampuan generalisasi matematik dan skala kepercayaan diri. Dari hasil perhitungan dan uji hipotesis dapat disimpulkan bahwa peningkatan kemampuan generalisasi matematik kelas eksperimen lebih baik secara signifikan dibanding dari kelas kontrol, kemudian sebagian besar siswa yang mendapatkan pembelajaran dengan pendekatan methaporical thinking dan mendapatkan kepercayaan diri yang lebih baik dibandingkan pembelajaran biasa.
\end{abstract}

Kata Kunci : Kemampuan Generalisai Matematis, Kepercayaan Diri

How to cite: Lesmana, L.A., Hidayat, W., Rohaeti, E.E. (2018). Meningkatkan Kemampuan Generalisasi Matematis dan Kepercayaan Diri Siswa dengan Menggunakan Pendekatan Metaphorical Thinking.JPMI - Jurnal Pembelajaran Matematika Inovatif, 1 (5), 863-872. 


\section{PENDAHULUAN}

Salah satu tujuan pendidikan adalah siswa dapat menggunakan penalaran pada pola dan sifat, melakukan manipulasi matematika dalam membuat generalisasi, menyusun bukti, atau menjelaskan gagasan dan pernyataan matematika. Namun, pada kenyataannya tujuan pendidikan ini belum terwujud. Hal tersebut terlihat dari hasil penelitian internasional terhadap prestasi belajar matematika siswa di Indonesia di antaranya dalam hasil penelitian PISA (Programme for International Student Assesment) tahun 2012 (Gurria, 2014) menyatakan prestasi siswa Indonesia pada matematika berada pada peringkat 64 dari 65 negara peserta studi dengan skor rata-rata 375, jauh dibawah rata-rata yaitu 494.Terlebih lagi kemampuan siswa Indonesia menyelesaikan soal level 5-6 hanya 0,3 sangat jauh dari rata-rata 12,6. Selain itu siswa berfikir, matematika pelajaran yang sulit dipelajari. Salah satu dampaknya yaitu kurangnya kepercayaan diri siswa dalam pembelajaran matematika (Hidayat, 2012). maka, diperlukan upaya perbaikan kualitas pembelajaran matematika oleh pemerintah.

Kemampuan penalaran merupakan salah satu tujuan pendidikan yang telah disebutkan diatas. penalaran terdiri dari penalaran induktif dan penalaran deduktif. Generalisasi merupakan salah satu kegiatan yang tergolong penalaran induktif dan merupakan aspek yang penting dalam proses berfikir. Karena dengan menggunakan generalisasi dapat membangun pemahaman konsep matematika yang baik dan meminimalisir kesalahan konsep dalam berfikir matematis siswa. Hal ini serupa dengan pendapat Hudojo (Nadia, 2012) " berfikir matematis merupakan kegiatan mental yang dalam prosesnya menggunakan generalisasi. Kekeliruan siswa dalam menggunakan generalisasi dapat menyebabkan sulitnya siswa dalam menemukan konsepkonsep matematika dengan baik". maka generalisasi matematis merupakan proses berfikir matematis yang menjadi modal dasar dalam memahami konsep matematika.

Berdasarkan hasil studi yang dilakukan oleh Priatna (Nadia, 2012) mengenai kemampuan penalaran dan pemahaman matematika siswa SLTP kelas 3, diperoleh temuan bahwa kualitas kemampuan penalaran (analogi dan generalisasi) dan pemahaman matematik rendah karena skor masing-masing hanya $49 \%$ dan $50 \%$ dari skor ideal. Hasil temuan tersebut menggambarkan bahwa perlu upaya penyelenggaraan pembelajaran yang optimal untuk meningkatkan kemampuan penalaran matematika siswa SMP, khususnya kemampuan generalisasi matematiknya. Agar tujuan pembelajaran dapat tercapai optimal, maka hendaknya digunakan pendekatan, strategi, metode atau teknik yang bervariasi yang menuntut siswa beraktifitas dalam mengikuti proses pembelajaran.

Generalisasi merupakan terjemahan dari kata generalization yang artinya perumunan. Rahman (Hermanto, 2011) mengatakan bahwa generalisasi adalah proses penarikan kesimpulan dimulai dengan memeriksa keadaan khusus menuju kesimpulan umum. Trisnadi (Nadia, 2012) yang mengungkapkan bahwa generalisasi adalah menyatakan pola, menentukan struktur/data/gambaran/suku berikutnya dan memformulasikan keumuman secara simbolis. Senada dengan Gagne (Nadia, 2012) mengartikan generalisasi sebagai transfer belajar, yaitu kemampuan seseorang untuk menangkap struktur pokok, pola dan prinsip-prinsip umum.

Indikator kemampuan generalisasi matematis menurut Mason (Hermanto, 2011) adalah : : a) Tahap perception of generality, b) Tahap ekspression of generality, c) Tahap symbolic expression of generality, d) Tahap manipulation of generality.

Selain kemampuan generalisasi, siswa juga harus memiliki rasa percaya diri. Kepercayaan diri sangatlah dibutuhkan oleh siswa agar mampu mengoptimalkan kemampuan yang dimilikinya. 
(Novtiar \& Aripin, 2017). Dengan percaya pada kemampuan diri sendiri tentunya siswa akan terbiasa mandiri dalam mengerjakan apapun termasuk mengerjakan permasalahanpermasalahan dalam matematika. Salah satu pendekatan yang dapat digunakan untuk mengatasi permasalahan diatas, yakni menggunakan pendekatan methaporical thinking.

Menurut Hendriana (2012), "Berpikir metaforik dalam matematika digunakan untuk memperjelas jalan pikiran seseorang yang dihubungkan dengan aktivitas matematiknya". Bentuk konseptua lmetafora meliputi: 1) Grounding methapors, 2) Linking methapors, 3) Redefinitional methapors.

Adapun kepercayaan diri adalah sikap menyakini kemampuan dirinya sendiri. Sikap percaya diri dalam setiap individu harus ditanamkan dan dilatih sejak dini. Dengan percaya pada kemampuan diri sendiri tentunya siswa akan terbiasa mandiri dalam mengerjakan apapun termasuk mengerjakan permasalahan-permasalahan dalam matematika.

\section{METODE}

Metode yang digunakan adalah metode eksperimen, kelas yang satu mendapat pembelajaran dengan pendekatan metaphorical thinking dan kelas yang lain mendapat pembelajaran biasa. Pada awal dan akhir pembelajaran kedua kelas diberi tes, sehingga desain penelitiannya adalah:

A $0 \times 0 \quad$ (Ruseffendi, 2010)

A 00

Keterangan:

A : Pemilihan sampel secara acak berdasarkan kelas

$0 \quad$ : Soal pretes $=$ soal postes

$\mathrm{X}$ : Pembelajaran menggunakan pendekatan metaphorical thinking.

Dalam penelitian ini populasinya adalah siswa SMP di Kota Bandung. Sampel yang diambil adalah siswa kelas VII di SMP Rahayu sebanyak dua kelas yaitu kelas ekperimen memperoleh pembelajaran menggunakan pendekatan methaporical thinking dan kelas kontrol memperoleh pembelajaran biasa.

Untuk memperoleh data dalam penelitian ini digunakan instrumen tes, yaitu seperangkat soal tes kemampuan generalisasi matematik. Untuk mengetahui seberapa besar peningkatan kemampuan generalisasi matematik siswa sebelum dan setelah kegiatan pembelajaran, dilakukan analisis skor gain ternormalisasi Hake (Nadia, 2012) dengan rumus sebagai berikut:

$$
g=\frac{\text { Skor Postes }- \text { Skor Pretes }}{\text { Skor Maksimum Ideal - Skor Pretes }}
$$

Tabel klasifikasi menurut Hake (Nadia, 2012) yaitu,

Tabel 1. Kriteria Skor Gain Ternormalisasi

\begin{tabular}{cc}
\hline Skor Gain & Interpretasi \\
\hline $\mathrm{g}>0.7$ & Tinggi \\
$0.3<\mathrm{g}>0.7$ & Sedang \\
$\mathrm{g}>0.3$ & Rendah \\
\hline
\end{tabular}




\section{HASIL DAN PEMBAHASAN}

\section{Hasil}

Setelah melaksanakan pembelajaran pada kedua kelas Selanjutnya dilakukan pengolahan data hasil penelitian. Tabel yang memuat nilai masing-masing kelas sebagai berikut :

Tabel 2. Data Deskriptif emampuan Generalisasi dan Kepercayaan Diri Siswa

\begin{tabular}{|c|c|c|c|c|}
\hline \multirow{2}{*}{ Kemampuan Generalisasi } & \multicolumn{2}{|c|}{ Kelas Eksperimen } & \multicolumn{2}{|c|}{ Kelas Kontrol } \\
\hline & $\overline{\boldsymbol{x}}$ & $s$ & $\overline{\bar{x}}$ & $s$ \\
\hline Pretes & 4,068 & 1,12 & 4,257 & 1,01 \\
\hline Postes & 12,000 & 1,89 & 10,745 & 2,06 \\
\hline Gain & 0,493 & 2,89 & 0,408 & 2,35 \\
\hline $\mathrm{N}$ & \multicolumn{4}{|c|}{35} \\
\hline \multirow{2}{*}{ Kepercayaan Diri } & \multicolumn{2}{|c|}{ Kelas Eksperimen } & \multicolumn{2}{|c|}{ Kelas Kontrol } \\
\hline & $\overline{\bar{x}}$ & $s$ & $\overline{\bar{x}}$ & $s$ \\
\hline Postes & 80,60 & 2,13 & 74,37 & 0,98 \\
\hline $\mathrm{N}$ & & & & \\
\hline
\end{tabular}

Berdasarkan Tabel 2 diketahui bahwa untuk aspek kemampuan generalisasi matematik, ratarata skor pretes pada kelas eksperimen lebih kecil dari pada kelas kontrol. Sedangkan, pada rata-rata skor postes dan gain kelas eksperimen lebih besar dibandingkan kelas kontrol. Dan skor rata-rata kepercayaan diri siswa kelas eksperimen lebih tinggi dibandingkan kelas kontrol. Untuk mendukung deskripsi peningkatan kemampuan generalisasi matematik dan kepercayaan diri siswa yang telah dijelaskan, maka dilakukan analisis data kemampuan generalisasi matematik siswa dan kepercayaan diri siswa melalui uji statistik dengan menggunakan uji perbedaan dua rata-rata.

\section{Analisisi Data Pretest Kemampuan Generalisasi Matematis}

a. Uji Normalitas

Tabel 3. Uji Normalitas Pretes Kemampuan Generalisasi Matematis

\begin{tabular}{llrcr}
\hline \multirow{2}{*}{ Kelas } & \multicolumn{3}{c}{ Kolmogorov-Smirnov $^{\mathrm{a}}$} \\
\cline { 3 - 5 } Pretest & Eksperimen & Statistic & Df & Sig. \\
& Kontrol & .216 & 35 & .000 \\
& .229 & 35 & .000 \\
\hline
\end{tabular}

Berdasarkan Tabel 3 terlihat bahwa nilai signifikansinya adalah 0,000 untuk kelas eksperimen dan 0,000 untuk kelas kontrol. Nilai signifikansi kelas eksperimen dan kelas control lebih kecil dari 0,05 maka $\mathrm{H}_{0}$ ditolak. Artinya sampel kelas eksperimen dan sampel kelas control tidak berdistribusi normal. Jika salah satu tidak berdistribusi normal maka dilanjutkan dengan uji persamaan dua rata-rata skor pretes yaitu uji Mann Whitney

b. Uji Non Parametrik Mann Whitney

Tabel 4. Hasil Uji Mann-Whitney Skor Pretes Kemampuan Generalisasi Matematis

\begin{tabular}{lr}
\hline & \multicolumn{1}{c}{ Pretes } \\
\hline Mann-Whitney U & 532.500 \\
Wilcoxon W & 1162.500 \\
Z & -.983 \\
Asymp. Sig. (2-tailed) & .325 \\
\hline
\end{tabular}


Dari Tabel 4 diatas, dapat dilihat bahwa nilai Asymp.Sig. (2-tailed) adalah 0.325 yang berarti nilai signifikansinya lebih besar dari taraf signifikansinya $\alpha=0,05$. Jadi, $\mathrm{H}_{0}$ diterima, artinya tidak terdapat perbedaan kemampuan awal pada aspek generalisasi matematis siswa SMP antara siswa yang pembelajarannya menggunakan pendekatan metaphorical thinking dengan pembelajaran biasa. Oleh karena itu, syarat bahwa PMT dan PB memiliki kemampuan awal yang sama terpenuhi.

\section{Analisis Data Postes Kemampuan Berpikir Generalisasi Matematis}

a. Uji Normalitas

Tabel 5. Uji Normalitas Postes Kemampuan Generalisasi Matematis

\begin{tabular}{lcrrr}
\multirow{2}{*}{ Kelas } & \multicolumn{3}{c}{ Kolmogorov-Smirnov } \\
\cline { 3 - 5 } & & Statistic & Df & \multicolumn{1}{c}{ Sig. } \\
\hline Postes & Eksperimen & .244 & 35 & .000 \\
& & & & \\
& Kontrol & .193 & 35 & .002 \\
\hline
\end{tabular}

Berdasarkan Tabel 5 terlihat bahwa nilai signifikansinya adalah 0,000 untuk kelas eksperimen dan 0,002 untuk kelas kontrol. Nilai signifikansi kelas eksperimen dan kelas control lebih kecil dari 0,05 maka $\mathrm{H}_{0}$ ditolak. Artinya sampel kelas eksperimen dan sampel kelas control tidak berdistribusi normal. Jika salah satu tidak berdistribusi normal maka tidak perlu dilakukan uji homogenitas, untuk uji persamaan dua rata-rata skor postes dilakukan dengan uji non parametrik uji Mann Whitney.

b. Uji Non Parametrik Mann Whitney

\section{Tabel 6}

Hasil Uji Mann-Whitney Skor Postes Kemampuan Generalisasi Matematis

\begin{tabular}{lllr}
\hline & & & \multicolumn{1}{c}{ Postes } \\
\hline Mann-Whitney U & & & 355.000 \\
Wilcoxon W & & 985.000 \\
Z & & -3.090 \\
Asymp. Sig. (2-tailed) & Sig. & .002 \\
Monte Carlo Sig. (2-tailed) & $95 \%$ Confidence & Lower & $.000^{\mathrm{b}}$ \\
& Interval & Bound & .000 \\
& & Upper & .042 \\
Monte Carlo Sig. (1-tailed) & Sig. & Bound & $.000^{\mathrm{b}}$ \\
& $95 \%$ Confidence & Lower & .000 \\
& Interval & Bound & \\
& & Upper & .042 \\
\hline
\end{tabular}

Dari Tabel 6 diatas, dapat dilihat bahwa nilai Sig. (1-tailed) adalah 0.00 yang berarti nilai signifikansinya lebih kecil dari taraf signifikansinya $\alpha=0,05$. Jadi, $\mathrm{H}_{0}$ ditolak, pencapaian kemampuan pada aspek generalisasi matematis siswa SMP antara siswa yang 
pembelajarannya menggunakan pendekatan metaphorical thinking lebih baik dibandingkan dengan pembelajaran biasa.

\section{Analisisi Data N-Gain Kemampuan Berpikir Generalisasi Matematis}

a. Uji Normalitas

Tabel 7

Normalitas N-Gain KemampuanGeneralisasiMatematis

\begin{tabular}{llrrr}
\hline & & \multicolumn{3}{c}{ Kolmogorov-Smirnov $^{\mathrm{a}}$} \\
\cline { 3 - 5 } & Kelas & Statistic & Df & \multicolumn{1}{c}{ Sig. } \\
\hline Gain & Eksperimen & .197 & 35 & .001 \\
& Kontrol & .131 & 35 & .137 \\
\hline
\end{tabular}

Berdasarkan Tabel 7 terlihat bahwa nilai signifikansinya adalah 0,001 untuk kelas eksperimen dan 0,137 untuk kelas kontrol. Nilai signifikansi kelas eksperimen lebih kecil dari 0,05 maka $\mathrm{H}_{0}$ ditolak. Artinya sampel kelas eksperimen tidak berdistribusi normal dan sampel kelas control berdistribusi normal. Jika salah satu tidak berdistribusi normal maka tidak perlu dilakukan uji homogenitas, untuk uji persamaan dua rata-rata gain dilakukan dengan uji non parametric uji Mann Whitney.

b. Uji Non Parametrik Mann Whitney

\section{Tabel 8}

Uji Mann-Whitney Skor N Gain Kemampuan Generalisasi Matematis

\begin{tabular}{lllr}
\hline & & & \multicolumn{1}{c}{ Gain } \\
\hline Mann-Whitney U & & & 388.500 \\
Wilcoxon W & & & 1018.500 \\
Z & & -2.637 \\
Asymp. Sig. (2-tailed) & & .008 \\
$\begin{array}{l}\text { Monte Carlo Sig. (2- } \\
\text { tailed) }\end{array}$ & Sig. & & $.000^{\text {b }}$ \\
& 95\% Confidence & Lower & .000 \\
& Interval & Bound & \\
& & Upper & .042 \\
Monte Carlo Sig. (1- & Sig. & Bound & $.000^{\text {b }}$ \\
tailed) & $95 \%$ Confidence & Lower & .000 \\
& Interval & Bound & \\
& & Upper & .042 \\
& & Bound & \\
\hline
\end{tabular}

Dari Tabel 6 diatas, dapat dilihat bahwa nilai Sig. (1-tailed) adalah 0.00 yang berarti nilai signifikansinya lebih kecil dari taraf signifikansinya $\alpha=0,05$. Jadi, $\mathrm{H}_{0}$ ditolak, peningkatan kemampuan pada aspek generalisasi matematis siswa SMP antara siswa yang pembelajarannya menggunakan pendekatan metaphorical thinking lebih baik dibandingkan dengan pembelajaran biasa. 


\section{Analisisi Data Kepercayaan Diri Siswa}

a. Uji Normalitas

Tabel 9

Uji Normalitas Kepercayaan Diri Siswa

\begin{tabular}{llrrr}
\hline \multirow{2}{*}{ Kelas } & \multicolumn{3}{c}{ Kolmogorov-Smirnov } \\
\cline { 3 - 5 } & & Statistic & Df & \multicolumn{1}{c}{ Sig. } \\
\hline Postes & Eksperimen & .118 & 35 & $.200^{*}$ \\
& & .195 & 35 & .002 \\
\hline
\end{tabular}

Berdasarkan Tabel 9 terlihat bahwa nilai signifikansinya adalah 0,200* untuk kelas eksperimen dan 0,002 untuk kelas kontrol. Nilai signifikansi kelas control lebih kecil dari 0,05 maka $\mathrm{H}_{0}$ ditolak. Artinya sampel kelas eksperimen berdistribusi normal dan sampel kelas control tidak berdistribusi normal. Jika salah satu tidak berdistribusi normal maka tidak perlu dilakukan uji homogenitas, untuk uji persamaan dua rata-rata skor kepercayaan diri dilakukan dengan uji non parametric uji Mann Whitney.

b. Uji Non Parametrik Mann Whitney

\section{Tabel 10}

Hasil Uji Mann-Whitney Kepercayaan Diri Siswa

\begin{tabular}{lllr}
\hline & & & Postest \\
\hline Mann-Whitney U & & & 278.500 \\
Wilcoxon W & & & 908.500 \\
Z & & -3.946 \\
Asymp. Sig. (2-tailed) & Sig. & .000 \\
Monte Carlo Sig. (2- & 95\% Confidence & Lower & $.000^{\mathrm{b}}$ \\
tailed) & Interval & Bound & .000 \\
& & Upper & \\
& & Bound & .042 \\
Monte Carlo Sig. (1- & Sig. & & $.000^{\mathrm{b}}$ \\
tailed) & $95 \%$ Confidence & Lower & .000 \\
& Interval & Bound & \\
& & Upper & .042 \\
\hline
\end{tabular}

Dari Tabel 10 diatas, dapat dilihat bahwa nilai Sig. (1-tailed) adalah 0.000 yang berarti nilai signifikansinya lebih kecil dari taraf signifikansinya $\alpha=0,05$. Jadi, $\mathrm{H}_{0}$ ditolak, kepercayaan diri antara siswa yang pembelajarannya menggunakan pendekatan $M T$ lebih baik dibandingkan dengan pembelajaran biasa.

\section{Pembahasan}

Dari hasil perolehan rata-rata pretes kelas eksperimen adalah 4.086 dari skor idealnya 20, dengan skor maksimal 7 dan skor minimal 2, serta simpangan baku 1.12. Sedangkan perolehan rata-rata pretes kelas kontrol adalah 4.257 dari skor idealnya 20, dengan skor maksimal 6 dan skor minimal 2, serta simpangan baku 1.01. Berdasarkan data tersebut terlihat bahwa rata-rata kelas eksperimen lebih kecil dari pada kelas kontrol, namun perbedaan tersebut tidak berarti bahwa kemampuan kelas kontrol lebih unggul daripada kelas 
eksperimen. Untuk mengetahui bahwa tidak ada perbedaan kemampuan awal generalisasi matematis kedua kelas secara signifikan, dilakukan uji persamaan rata-rata ( 2 pihak), sebelum melakukan uji tersebut terlebih dahulu dilakukan uji normalitas dan uji homogenitas, dengan taraf signifikansi 0,05. Uji normalitas pretes dilakukan menggunakan software SPSS22 dengan uji Kolmogorov-Smirnov, dari uji normalitas tersebut diperoleh data bahwa kelas eksperimen berdistribusi normal sedangkan kelas kontrol tidak berdistribusi normal sehingga uji signifikasi persamaan rata-rata (2 pihak) dilakukan uji non parametrik uji Mann Whitney dan diperoleh nilai signifikansinya sebesar 0.325 , yang berarti bahwa tidak terdapat perbedaan kemampuan awal pada aspek generalisasi matematis pada kedua kelas

Setelah diperoleh hasil bahwa kemampuan awal generalisasi matematis kedua kelas sama, selanjutnya kedua kelas diberikan perlakuan berbeda. Kelas eksperimen menerapkan pembelajaran dengan pendekatan $M T$ dan kelas kontrol dengan pembelajaran biasa.

Kemudian dilakukan postes untuk melihat apakah dengan pendekatan MT kemampuan generalisasi siswa menjadi lebih baik dibandingkan dengan pembelajaran biasa. Dari hasil diperoleh rata-rata postes kelas eksperimen adalah 12.00 dari skor idealnya 20, dengan skor maksimal 18 dan skor minimal 10, serta simpangan baku 1.89. Sedangkan perolehan rata-rata postes kelas kontrol adalah 10.745 dari skor idealnya 20, dengan skor maksimal 16 dan skor minimal 7, serta simpangan baku 2.06. Sedangkan untuk perolehan rata-rata skor kepercayaan diri akhir sebesar 80.60 sedangkan untuk kelas kontrol rata-rata skor kepercayaan diri sebesar 74.37, dari data yang diperoleh tampak bahwa kelas eksperimen mengalami persentase pencapaian kepercayaan diri yang lebih tinggi. Berdasarkan data tersebut terlihat bahwa ratarata kelas eksperimen lebih baik dibandingkan kelas kontrol. Namun untuk membuktikan hal tersebut data dari kedua kelas tersebut diuji menggunakan SPSS.

Untuk mengetahui perbedaan peningkatan kemampuan generalisasi matematis kedua kelas secara signifikan, dilakukan uji persamaan rata-rata (1 pihak), sebelum melakukan uji tersebut terlebih dahulu dilakukan uji normalitas dan uji homogenitas, dengan taraf signifikansi 0,05. Uji normalitas pretes dilakukan menggunakan software SPSS23dengan uji KolmogorovSmirnov, dari uji normalitas tersebut diperoleh data bahwa kelas eksperimen tidak berdistribusi normal sedangkan kelas kontrol berdistribusi normal sehingga uji signifikasi persamaan rata-rata (1 pihak) dilakukan uji non parametrik uji Mann Whitney dan diperoleh nilai signifikansinya sebesar 0.000 , yang berarti bahwa kemampuan generalisasi matematis siswa kelas eksperimen lebih baik daripada kelas kontrol. Begitupun dengan pencapaian kepercayaan diri siswa setelah dilakukan uji statistic diperoleh hasil signifikansinya sebesar 0.000 , yang berarti pencapaian kepercayaan diri kelas eksperimen lebih baik dari pada kelas kontrol.

Hal ini sejalan dengan penelitian yang diakukan oleh Nurhikmayati (2013) pada siswa kelas VIII di SMPN 3 Lembang, diperoleh kesimpulan bahwa peningkatan kemampuan pemahaman dan penalaran matematis siswa SMP yang mendapat pembelajaran dengan pendekatan metaphorical thinking lebih baik daripada siswa yang mendapatkan pembelajaran biasa.

Serta menurut Warman (Efendi, 2016) bahwa tingkat hasil kepercayaan diri dipengaruhi oleh percaya diri siswa tinggi dan sebaliknya rendah hasil kepercayaan diri dipengaruhi oleh rendahnya percaya diri siswa itu sendriri. Berkaitan dengan hasil penelitian yang dilakukan Hidayat (Dini, 2018) menunjukkan bahwa siswa yang memiliki Self Confidence tinggi dapat 
membentuk keyakinan pada dirinya tentang kemampuan untuk pantang menyerah dalam menghadapi permasalahan yang diberikan.

\section{KESIMPULAN DAN SARAN}

Berdasarkan hasil penelitian dan pengolahan data pada keseluruhan tahapan penelitian, maka dapat diambil kesimpulan:

1. Kemampuan generalisasi matematis siswa yang pembelajarannya menggunakan pendekatan metaphorical thinking lebih baik daripada siswa yang pembelajarannya menggunakan pembelajaran biasa.

2. Kepercayaan diri siswa yang menggunakan pendekatan metaphorical thinking lebih baik daripada yang menggunakan pembelajaran biasa

\section{DAFTAR PUSTAKA}

Dini, M. (2018). Pengaruh Self Confidence Terhadap Kemampuan Pemahman Matematik Siswa SMP. Jurnal Silogisme, 1(3), 1-7.

Efendi, D. Y. (2016). Meningkatkan Kemampuan dan Koneksi Serta Kepercayaan Diri Matematik Siswa SMP mealui Pendekatan Generatif.

Gurria, A. (2012). Results: What Students Know and Can Do Student Performance in Mathematics, Reading and Science. vol. 1. US:OECD. Revised edition.

Hendriana, H.(2012). Pembelajaran Matematika Humanis dengan Metaphorical Thinking untuk Meningkatkan Kepercayaan Diri Siswa. Infinity Jurnal Ilmiah Program Studi Matematika STKIP Siliwangi Bandung. Vol. 1, No.1., 2012

Hidayat, W. (2012). Meningkatkan Kemampuan Berpikir Kritis dan Kreatif Matematik Siswa SMA melalui Pembelajaran Kooperatif Think-Talk- Write. Prosiding Seminar Nasional Penelitian, Pendidikan dan Penerapan MIPA, Fakultas MIPA Universitas Negeri Yogyakarta.

Hermanto, R. (2011). Pengaruh Pembelajaran Kooperatif Tipe STADBerbantuan Program Sketchpad Terhadap Kemampuan Generalisasi Matematik Siswa SMP. Tesis Upi. Bandung : Tidak diterbitkan

Nadia, N. (2012). Penerapan Model Pembelajaran Kooperatif Tipe JIGSAW Dengan Pendekatan Pemecahan Masalah Untuk Meningkatkan Kemampuan Generalisasi Matematis Siswa: Penelitian Eksperimen Terhadap Siswa Kelas VII SMP di Bandung.

Novtiar, C., \& Aripin, U. (2017). Meningkatkan Kemampuan Berfikir Kritis Matematis Dan Kepercayaan Diri Siswa Smp Melalui Pendekatan Open Ended. Prisma,6(2)

Ruseffendi, E. . (2010). Dasar-dasar Penelitian Pendidikan dan Bidang non Eksata Lainnya. Bandung: Tarsito.

Suhendri, H. 2012. Pengaruh Kecerdasan Matematis-Logis, Rasa Percaya Diri, Dan Kemandirian Belajar Terhadap Hasil Belajar Matematika. Prosiding Seminar Nasional Matematika dan Pendidikan Matematika UNY 10 November 2012 
872 Lesmana, Hidayat \& Rohaeti, Meningkatkan Kemampuan Generalisasi Matematik..... 